Araştırma Makalesi - Research Article

\title{
YAYsim: Salgın Modelleme ve Karar Destek Sistemi
}

Geliş / Received: 16/01/2020

\author{
Mustafa DEMİRBİLEK ${ }^{1 *}$
}

ÖZ

Revize / Revised: 13/03/2020

Kabul / Accepted: 22/04/2020

İnsanlık tarihinin başlangıcından itibaren kızıl, kızamık, grip, AIDS gibi bulaşıcı hastalıklar milyonlarca insanın hastalanmasına ve ölmesine, büyük iş gücü kayıplarına ve çok yüksek ekonomik maliyetlere sebep olmuştur. Aşı, karantina ve ilaç gibi müdahale yöntemlerinin, kıt kaynaklar ve maliyetler düşünüldüğünde etkili bir şekilde kullanılmaları için bulaşıcı hastalıklara neden olan bakteri ve virüslerin bir topluluk içinde yayılma dinamiklerinin iyi analiz edilmiş olması gerekmektedir. SIR (Susceptable-Infected-Recovered) bölmeli modelleme yöntemi yaklaşık bir asırdır bulaşıcı hastalıkların bir populasyon içinde yayılma dinamiklerinin modellemesinde ve toplam hasta ve ölü sayısının, hastalığın ekonomik boyutlarının tahmininde kullanılmaktadır. $\mathrm{Bu}$ makalede, karar vericilerin ve ilgili kullanıcıların, hastalık şiddeti, iyileşme periyodu, başlangıçtaki hasta sayısı gibi salgın parametrelerini değiştirebilmesine izin vererek, salgının sonuçlarını analiz edebilmelerine yardım edecek, python programlama dilinde kodlanan, YAYsim isimli karar destek programı geliştirilmiştir. YAYsim, Türkiye'deki her şehrin nüfus bilgilerini içermektedir. Bu sayede kullanıcıların, seçilmiş bir şehirde yaşanabilecek bir salgının sonuçlarını görebilmelerine ve bu sonuçlara göre çalıştıkları disiplinler çerçevesinde karar verebilmelerine olanak sağlamaktadır. Son olarak Gaziantep ilinde yaşanabilecek olası bir H1N1 salgını sırasında oluşabilecek hasta ve ölü oranlarını tahmin etmek ve değerlendirmek için örnek bir çalışma yapılmıştır. 1918 İspanyol Gribi yayılma parametreleri baz alınarak yapılan modellemede, Gaziantep nüfusunun \%35.8'inin hastalıktan etkilendiği ve \%0.7'sinin hayatını kaybettiği gözlenmiştir.

Anahtar Kelimeler- Benzetim, Karar destek sistemi, Salgın modelleme

1*Sorumlu yazar iletişim: mustafa.demirbilek@gibtu.edu.tr (http://orcid.org/0000-0002-1520-2882)

Endüstri Mühendisliği Bölümü, Gaziantep İslam Bilim ve Teknoloji Üniversitesi 


\title{
YAYsim: Modelling Outbreak and Decision Support System
}

\begin{abstract}
Infectious diseases such as measles, morbillivirus, influenza, AIDS have caused millions of infecteds and deaths, great workforce lost and economical cost since the beginning of civilization. The spread dynamics of bacteria and viruses that cause infectious diseases through a population is carefully analysed to be able to effectively use intervention methods such as vaccination, quarantine, medicine, and etc. while considering scarce resources and costs. SIR (Susceptable-Infected-Recovered) compartmental model has been used to model spread dynamics of infectious diseases through a population, to predict total number of infected and death people and to calculate economical cost of diseases for roughly a century. In this study, we develop a software, YAYsim, coded in Python programming language, to be able to help decision makers and interested users to analyse results of an epidemic or pandemic by allowing them to change disease parameters as attack rates, recovery periods, the number of infected people at the beginning. YAYsim includes demografic information of each city in Turkey. Thus, it enables users to see how a pandemic affects on a selected city and to be able to decide based on their working area according to the results. Finally, an example study is carried out to estimate and evaluate rates of infected and death people during a possible H1N1 pandemic in Gaziantep city. It is observed that $35.8 \%$ of Gaziantep's population are affected from the disease and $0.7 \%$ of them are death based on the disease parameters of 1918 Spanish Flu.
\end{abstract}

Keywords- Simulation, Decision support system, Modelling outbreak 


\section{GIRIŞ}

İncil'de geçen kara veba salgınlardan bugünkü HIV salgınına kadar bulaşıcı hastalıklar tartışmasız insan tarihinde büyük rol oynamışlardır. İnsanların farklı kıtalara yayılması ile birlikte, yeni patojenler ortaya çıkmış ve büyük salgınlara yol açmışlardır. 1918 İspanyol Gribi sırasında 20 ile 50 miyon arasında insanın öldüğü tahmin edilmektedir ki bu, 1. Dünya Savaşı' nda ölenlerin toplamından çok daha fazladır [1]. 2014-2016 arasında görülen ebola salgını Orta ve Batı Afrika'yı büyük oranda etkilemiş, hastalığa bağlı ortalama ölüm oranı \%50'lere yükselmiştir [2].

Ülkemizde de hem Osmanlı Devleti'nin son dönemlerinde hem de Cumhuriyet'in ilk zamanlarında salgın hastalıklarla mücadele edilmiştir. Sıtma vakalarının görünme oranı Ankara da \%90, İstanbul da $\% 80$ ve diğer büyük şehirlerde $\% 70$ kadar ulaşabilmekteydi [3]. Son yıllarda da kuş ve domuz gribi endemikleri, hastalıklara, iş gücü kayıplarına ve ölümlere neden olmaktadır. Diğer yandan Suriyeli vatandaşların, kontrolsüz bir şekilde ülkemiz içine dağılması, uzun yıllar önce etkin aşılama yöntemleriyle etkisini yitiren kızamık, çocuk felci ve tüberkiloz gibi hastalıkların yeniden bir salgın haline gelmesi riskini de beraberinde getirmektedir.

Bulaşıcı hastalıkların yayılmasına engel olabilmek, en uygun müdahale metodunu seçebilmek ve gıda, su, ilaç stoklama, gerekli personel ve ekipmaları hazır bulundurma, gereken bölgelere acil operasyon merkezleri kurulması, ulaşım-lojistik-haberleşme faaliyetlerinin organize edilmesi gibi afet yönetimi kapsamında önlemler alabilmek için hastalığın topluluk içinde yayılma dinamikleri iyi analiz edilmelidir. Bu analiz yöntemlerinden, araştırmacıların en çok başvurduklarından biri, Bölmeli (Compartmental) Modelleme yöntemidir. Bu çalışmada yaşanacak olası salgını modellemek için en basit bölmeli modelleme yöntemi olan SIR (Susceptable-InfectedRecovered) modeli kullanılmıştır. Model ile ilgili detaylar bir sonraki bölümde açıklanacaktır.

İlk olarak 1927 y1lında Kermack and McKendrick tarafından ortaya konan bölmeli modeller ve matematiksel formulasyonundan itibaren [4] günümüze kadar, bulaşıcı hastalıkların yayılmasını, sonuçlarını ve çeşitli müdahale stratejilerinin uygulanmasını içeren çok sayıda çalışma yayınlanmıştır [5][6]. Bu çalışmalar, çeşitli matematiksel çözümler ve benzetim tabanlı nümerik analizler içerip, ilgilenenlerin ve karar vericilerin direkt olarak kullanabileceği ve değişiklik yapabileceği yapıda değildirler. Bu çalışmanın amacı bulaşıcı hastalıkların yayılmasını modelleyen bir arayüz oluşturmak ve son kullanıcıların en kolay şekilde yararanmasını sağlamak olduğundan, burada bilgi verilecek makaleler, diğer araştırmacıların, ilgililerin ve karar vericilerin kullanabilmesi için kullanıcı arayüzü ve/veya açık kaynak kod sağlayan çalışmalardan seçilmiştir. Chao vd. [7] $\mathrm{C} / \mathrm{C}++$ programlama dilini kullanarak, nesne tabanlı FluTe modelini geliștirdi. Bu modelle Birleşik Devletler'in Seattle eyaletinde çıkacak olası bir grip salgının sonuçlarını değerlendirdiler. Hladish vd. [8] C++ programlama dili kullanarak yine nesne tabanlı modeller geliştirdiler. Farklı şebeke yapıları ve bulaşma modellerini düşünerek salgınların yayılma dinamiklerini ortaya koydular. Liu vd. [9] bulaşıcı hastalıkların yayılmasını, veri yönetimi ve analitiği yönünden modelleyen bir karar destek sistemi tasarladılar. Modellerinde Birleşik Devletler ulaşım ağı, nüfus yapısı ve coğrafi özelliklere yer verdiler. Edlund vd. [10] java tabanlı açık kaynak kodlu, sadece ulaşım ağları ve coğrafi özellikleri değil ayrıca bazı hayvan türlerinin göç yolları ve zamanlarını dikkate alarak bir yazılım tasarladılar. Amaçları, insanlar arasındaki bulaşmanın modellenmesinin yanı sıra hayvanlardan insanlara geçebilen hastalıkların da düşünülmesiydi. Grefenstette vd. [11] C++ programlama diliyle FRED adında nesne tabanlı bir program geliştirdiler. Birçok programın aksine, popülasyondaki bireylerin birbirleriyle karışık olarak interaksiyonundan ziyade, bireylerin ev ve iş durumlarına göre interaksiyonu modele dahil edilmiştir. Bu şekilde karantina ve okul/iş yeri kapatılma durumları modellenebilmektedir. Kuylen vd. [12] python tabanlı STRIDE isimli yazılım geliştirdiler. STRIDE farklı yaş gruplarını, sosyal yapıları ve kontak sayılarını baz alarak hastalık yayılımını tahmin etmekte ve sonuçları öngörmekte kullanılmaktadır. Ramirez vd. [13] R programlama dili tabanlı, coğrafi konumlama sistemini de içeren, Kanada'daki bazı eyalet ve şehirleri kapsayan bir model tasarladılar. FRED'e benzer şekilde, iş yeri, ev ve okul gibi hastalığın farklı yayılma dinamikleri gösterebileceği yerleri de modele dahil ettiler. Aşılama ve karantina gibi bazı müdahale stratejileri de modellerinde yer almaktadır.

Yukarıda sayılan modeller ve yazılımlar araştırmacılar için önemli olanaklar sunsalar da, kompleksliklerinden kaynaklanan bazı problemleri de beraberlerinde getirmektedirler. Bazıları kullanıcı arayüzü içermemekte ve Microsoft Visual Studio ve Eclipse gibi programlarla beraber çalışmaktadırlar. Bundan dolayı kodlamaya hakim olmayanlar için kişisel bilgisayarlarına indirmeleri ve kullanmaları epey zordur. Web 
arayüzüne sahip bazı programlar ise geliştirenlerin izin verdiği kadar ve internet bağlantısının gücü ölçüsünde kullanılabilmektedir. Son olarakta senaryolar çoğunlukla Batı Avrupa ve Kuzey Amerika kıtasındaki devletlerin demografik yapıları referans alınarak tasarlanmıştır. Bu makalede geliştirilen yazılım, daha sonra açıklanacağı üzere Microsoft Windows tabanlı bütün bilgisayarlarda rahatça kurulup çalıştırılabilecek, yüksek ram ve işlemci gerektirmeyecek şekilde tasarlanmıştır. Basit ve türkçe kullanıcı arayüzüyle her seviyeden bilgisayar kullanıcısının rahatlıkla kullanabileceği ve benzetim girdilerini manipüle edebileceği şekilde dizayn edilmiştir. En önemlisi de, Türkiye'de her şehrin demografik bilgilerini, 2018 TÜİK adrese dayalı kayıt sisteminden temin ederek, kullanıcıların her şehir için olası salgınları modellemeleri ve olası vaka sayılarını hesaplamaları sağlanmıştır.

Ayrıca bu çalışmada, Gaziantep'te yaşanabilecek olası bir H1N1 (Domuz Gribi) virüsü salgınının modellemesi örnek çalışma olarak sunulmuştur. Kullanıcıların sonuçları nasıl yorumlayacağı ile ilgili bilgi vermek amaçlanmıştır. Grip aşısının ve ilacının optimal şekilde dağıtılması için gelecekte yapılacak çalışmalara da 1şık tutacaktır.

\section{BENZETIM MODELİ VE VERILER}

Bu bölüm iki kısımda incelenecektir. Birinci kısımda bölmeli model ile ilgili bilgi verilecektir. İkinci kısımda model için gerekli olan veriler incelenecektir.

\section{A. Model}

İlk olarak 1927 yılında Kermack and McKendrick tarafından geliştirilen bölmeli modeller bulaşıcı hastalıkların yayılmasını modelleme de kullanılmaktadır [4]. Her bir bölme, aynı karakteristiklere sahip olan bireyleri içermektedir. Her bir zaman aralığında (dakika, saat, gün, vb.), belirli sayıda kişi başka bir bölmeye hareket eder. Bu modelin temel varsayımı, her bir bölmenin içindeki bireyler birbirleriyle ve farklı bölmelerdeki bireylerle rassal olarak kontağa geçebileceğidir. Gerçek hayatta, bireylerin kontak kurduğu kişi sayısı sınırlıdır ve homojen değildir. Bölmeli modeller bunu gözardı etmesine rağmen, büyük populasyonların hızlı ve doğru biçimde modellenmesinde hala etkili bir yöntemdir [14][15][16].

$\mathrm{Bu}$ çalışmada, en basit bölmeli model olan SIR (Susceptible-Infectious-Recovered) model kullanılmıştır. Parantez içindeki ingilizce kelimeler sırasıyla korunmasız, hasta ve iyileşmiş anlamlarına gelmektedir ve herbiri bir bölmeyi temsil etmektedir. Diğer bir ifadeyle korunmasız bölmesinde henüz hastalığa yakalanmamış kişiler, hasta bölmesinde hasta bireyler ve son olarakta iyileşmiş bölmesinde hastalıktan kurtulmuş bireyler bulunmaktadır. Belirli bir zaman aralığında hasta ve korunmasız bireyler etkileşime geçip, belirli bir oranda birey hasta olmakta ve korunmasız bölmesinden hasta bölmesine geçmektedir. Benzer şekilde iyileşme sürecine bağlı olarak belirli sayıda hasta birey iyileşmiş bölmesine geçmektedir. Şekil 1. süreci temsil etmektedir. Hastalığın bulaşıcılığına ve iyileşme süresine göre $\beta$ ve $r$ çarpanları değişmektedir.

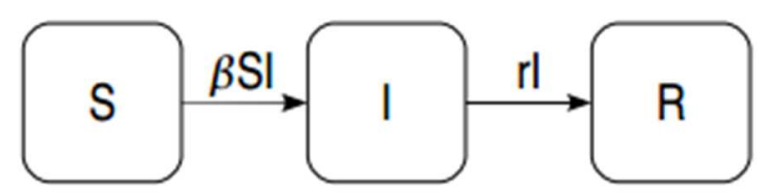

Şekil 1. SIR bölmeli modeli ve geçiş çarpanlanı

Hastalığın bulaşması farklı yaş gruplarına göre değişiklik gösterdiği için her şehrin nüfusu, 0-4, 5-19, 20-49, 50-64, 65+ olarak beş farklı yaş grubuna bölünmüştür. Yaş grubu $a \in G$ içindeki her bir birey, belli bir zaman aralığında 3 bölmeden birinde bulunmalıdır. Toplam nufüs sayısına $N$ olarak tanımlanırsa:

$$
\sum_{a \in G} N_{a}=N
$$


Başlangıçta sisteme tanımlanan hasta kişiler hariç bütün bireyler korunmasız bölmesine yerleştirilmiştir. Korunmasız bireyler her yaş grubundan belirli sayıda hasta bireyle her gün kontağa geçer ve kontak sayısı ve bulaşma oranına bağlı olarak hasta olurlar. Her yaş grubundaki bireylerin diğer bireylerle günlük kontak sayıları Mossong vd. [17]'nin çalışmalarından Tablo 1'de gösterildiği gibi elde edilmiştir. Yaş grubu $a$ 'daki kişilerin, yaş grubu $b$ 'de bulunan hasta kişilerle kontaktan kaynaklanan, günlük yeni hasta sayısı oranı, $\mu_{\mathrm{a}, \mathrm{b}}$, aşağıdaki gibi formülize edilebilir:

$$
\mu_{a, b}=\frac{p_{b} c_{a, b} I_{b}}{N_{b}}
$$

$p_{b}$, korunmasız bir kişinin $b$ yaş grubundan hasta kişilerle tek bir kontakta hasta olma oranını temsil eder. $C_{a, b}$ Tablo 1 de gösterildiği gibi yaş grupları arasındaki günlük kontak sayısını, $I_{b}$ ise $b$ yaş grubunda ki toplam hasta kişi sayısını göstermektedir. Bir günün sonunda oluşabilecek $a$ yaş grubunda toplam hasta sayısı oranı aşağıdaki gibi hesaplanabilir:

$$
\sum_{b \in G} \mu_{a, b}=\mu_{a}
$$

Aşağıdaki denklemler sırasıyla korunmasız (4), hasta (5) ve iyileşmiş (6) bölmelerindeki kişi sayısının günlük değiş̧imini ve günlük ölüm (7) sayısını vermektedir:

$$
\begin{aligned}
& \frac{d S_{a}}{d t}=-\mu_{a} \mathrm{~S}_{a} \quad a \in G \\
& \frac{d I_{a}}{d t}=\mu_{a} \mathrm{~S}_{a}-\mathrm{I}_{a} \beta-\mathrm{I}_{a} \rho_{a} \quad a \in G \\
& \frac{d R_{a}}{d t}=\mathrm{I}_{a} \beta \quad a \in G \\
& \frac{d D_{a}}{d t}=\mathrm{I}_{a} \rho_{a} \quad a \in G
\end{aligned}
$$

Günlük iyileşme oranı $\beta$ ile gösterilmektedir ve 1/iyileşme süresine eşittir. Yaş grubu $a$ 'daki hasta bireylerin günlük ölüm oranları da $\rho_{a}$ 'dır. Tablo 2 'de $\beta$ ve her yaş grubu için $\rho$ ve $p$ oranları verilmiştir.

Tablo 1. Her yaş grubu için günlük kontak sayıları

\begin{tabular}{lccccc}
\hline & $\mathbf{0 - 4}$ & $\mathbf{5 - 1 9}$ & $\mathbf{2 0 - 4 9}$ & $\mathbf{5 0 - 6 4}$ & $\mathbf{6 5 +}$ \\
\hline $\mathbf{0 - 4}$ & 1.92 & 1.30 & 1.57 & 0.76 & 0.39 \\
$\mathbf{5 - 1 9}$ & 0.58 & 8.72 & 2.16 & 1.09 & 0.85 \\
$\mathbf{2 0 - 4 9}$ & 0.67 & 2.28 & 3.33 & 2.29 & 1.10 \\
$\mathbf{5 0 - 6 4}$ & 0.30 & 0.91 & 1.66 & 2.38 & 1.69 \\
$\mathbf{6 5 +}$ & 0.12 & 0.45 & 0.94 & 1.48 & 1.93 \\
\hline
\end{tabular}

\section{B. Benzetim Ayarlarl ve Kalibrasyonu}

Bölmeli modellerin analitik çözümü olmadığı için yaklaşık çözüm için nümerik simülasyon yöntemi kullanılmıştır. 120 günlük salgın süresi tanımlanmış ve salgının pik zamanı olarak tam ortası seçilmiş̧tir. Hastalığın yayılma hızı 1918 İspanyol gribi değerlerine göre kalibre edilmiştir [18]. Gerçekleşmiş değerlerle kalibrasyondan sonraki değerler Tablo 2'de ilk iki satırda görülebilir. Hemen altında hasta bireylerin günlük ölüm oranları verilmiştir [16]. İyileşme periyodu ve başlangıç hasta sayısı kullanıcının isteğine bağlı olarak Tablo 2.'deki değer aralıklarında seçilebilir. 
Tablo 2. Benzetim parametreleri

\begin{tabular}{lccccc}
\hline & $\mathbf{0 - 4}$ & $\mathbf{5 - 1 9}$ & $\mathbf{2 0 - 4 9}$ & $\mathbf{5 0 - 6 4}$ & $\mathbf{6 5 +}$ \\
\hline Yayılma Oranları (\%) & 33.7 & 37.2 & 28.7 & 16.2 & 11.8 \\
Kalibrasyon (\%) & 33.8 & 37.2 & 26.2 & 16.7 & 12.2 \\
Ölüm Oranları & 0.0049 & 0.002 & 0.0056 & 0.0038 & 0.001 \\
İyileşme Periyodu & & & $3-8$ & & \\
Başlangıç Hasta Sayısı & & & $5-20$ & & \\
\hline
\end{tabular}

Nüfus bilgileri TÜİK'in 2018 ikamet edilen illere göre nüfus bilgisi kayıtlarında elde edilmiştir.

\section{YAYsiM}

Bu bölümde geliştirilmiş arayüz ve örnek çalışma ile ilgili bilgiler verilecektir.

\section{A. YAYsim Arayüz Bilgileri}

Program çalıştırıldıktan sonra Şekil 2.'deki arayüz ekrana gelecektir. En üstteki satır, hastalığın yayılması için başlangıçtaki hasta kişi sayısını tanımlamak için kullanılmaktadır. Hemen altında hasta olan bir kişinin kaç günde iyileşeceği bilgisinin girebileceği sekme bulunmaktadır. Tablo 2.'de bunlar ile ilgili aralıklar verilmiştir. Üçüncü satırda hastalığın kalibrasyonunun yapılabildiği sekme bulunmaktadır. Daha önceden belirtildiği gibi hastalığın şiddeti 1918 İspanyol Gribi değerlerine göre kalibre edilmiştir. Başlangıç hasta kişi sayısı ve iyileşme periyodu değeri değiştirilmezse, bu sekmedeki değer 1 olduğunda benzetimin sonuçları 1918 İspanyol Gribi değerlerine benzer olacaktır. Hastalığın bulaşma şiddeti bu sekme aracılığı ile belli bir sıkalada artırılabilir veya azaltılabilir. Son olarak hastalığın yayılmasını inceleyeceğimiz şehri sekme aracılığı ile belirleyebilir veya ülke genelinde nasıl sonuçlar doğurabileceğini görmek istiyorsak en baştaki "Türkiye" seçeneğini getirebiliriz.

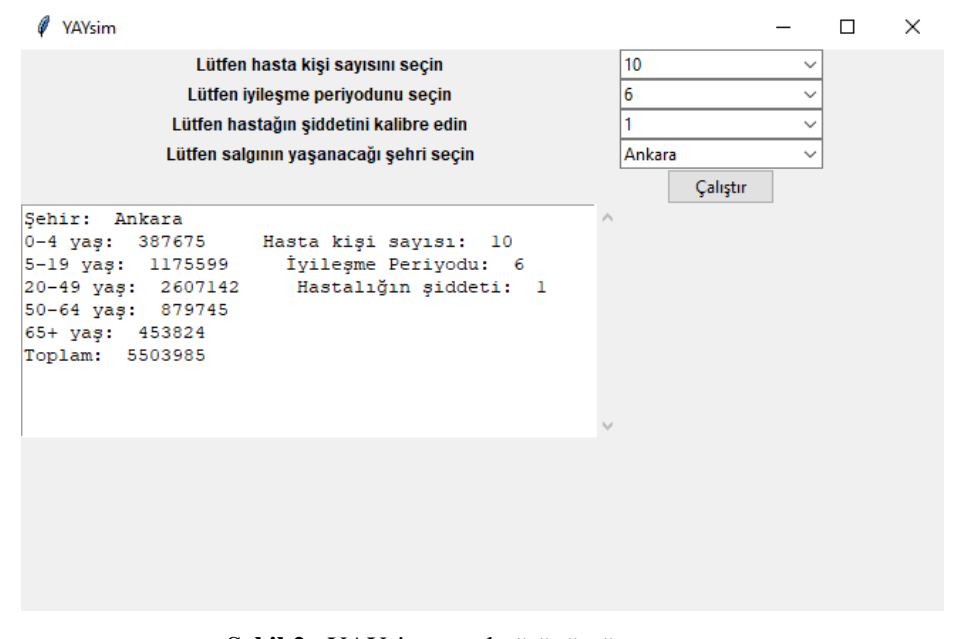

Şekil 2. YAYsim genel görünümü

Şekil 3.'de değiştirilen parametrelere göre sol altta bulunan bilgi ekranının değişimi gösterilmiştir. Değişiklik yapılan bilgiler anında bilgi ekranında görünmektedir. Farklı bir şehir seçildiğinde, nüfusun farklı yaş gruplarına göre dağılımı Şekil 3.'deki İstanbul örneğinde olduğu gibi değişmektedir. İstenilen parametreler ayarlandıktan sonra "Çalıştı" butonuna basıldığında benzetim çalışmakta ve sonuçlar bilgi ekranının altında sonuç ekranında Şekil 4.’deki gibi görülmektedir. Her parametre değişimi sonrası benzetim çalıştırıldığında sonuç ekranı da yeni gelen bilgiler 1şığında güncellenmektedir. 


\begin{tabular}{|c|c|c|}
\hline & $\begin{array}{l}\text { BŞEÜ Fen Bilimleri Dergisi } \\
7(1), 104-112,2020\end{array}$ & $\begin{array}{r}\text { BSEU Journal of Science } \\
\text { DOI: } 10.35193 / \text { bseufbd.675734 }\end{array}$ \\
\hline & & 58-7575 (http://dergipark.gov.tr/bseufbd) \\
\hline
\end{tabular}

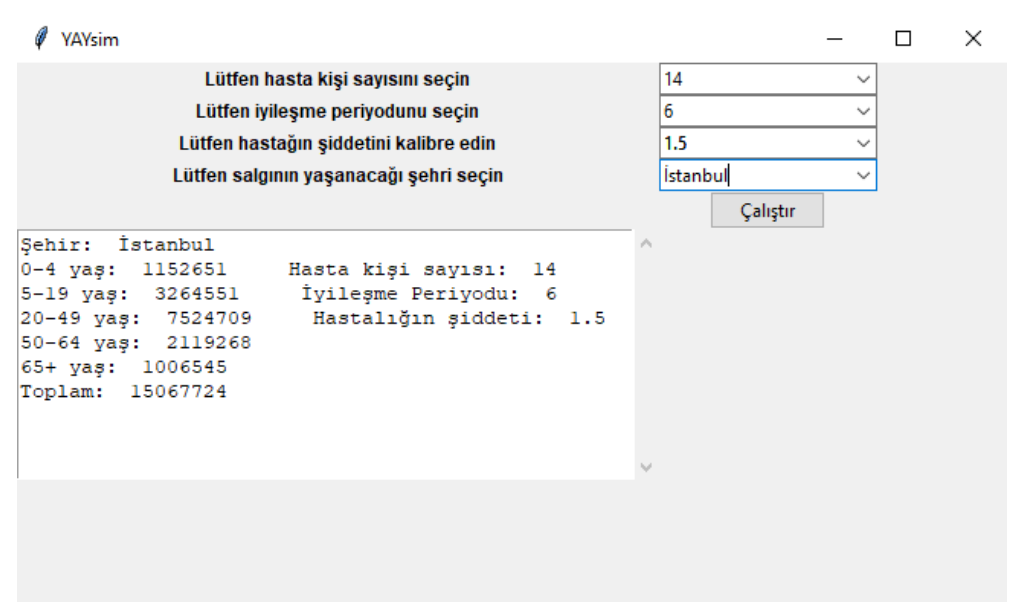

Şekil 3. YAYsim bilgi ekranı

Şekillerde görüldüğü gibi YAYsim kullanımı çok basit ve pratik olan bir programdır. İlk açılışta kullanılan bilgisayarın hızına göre değişmekle birlikte saniyeler sürmektedir. Seçenekler ve bilgi ekranı türkçe olarak minimalist bir biçimde tasarlanmıştır. Hastalık parametreleri, literatürdeki diğer çalışmalar baz alınarak belli aralıklarda sınırlandırılmıştır. Bir sonraki bölümde örnek bir uygulama yapılıp sonuçlar değerlendirilecektir.

\section{B. Örnek Çalışma ve Sonuçlar}

Yukarıda YAYsim'in nasıl kullanılacağı basit bir şekilde anlatılmıştır. Bu bölümde Gaziantep şehrinde olası bir grip pandemiği sonuçları irdelenecektir. Şekil 4.'deki gibi gerekli hastalık parametleri girilip, Gaziantep ili seçilip, "Çalıştır" butonuna basıldıktan sonra bilgi ekranının altında sonuçların görüntülendiği ekran çıkmaktadır. Burada yaş gruplarına göre kaç kişinin hasta olduğu ve öldüğü görülebilmektedir.

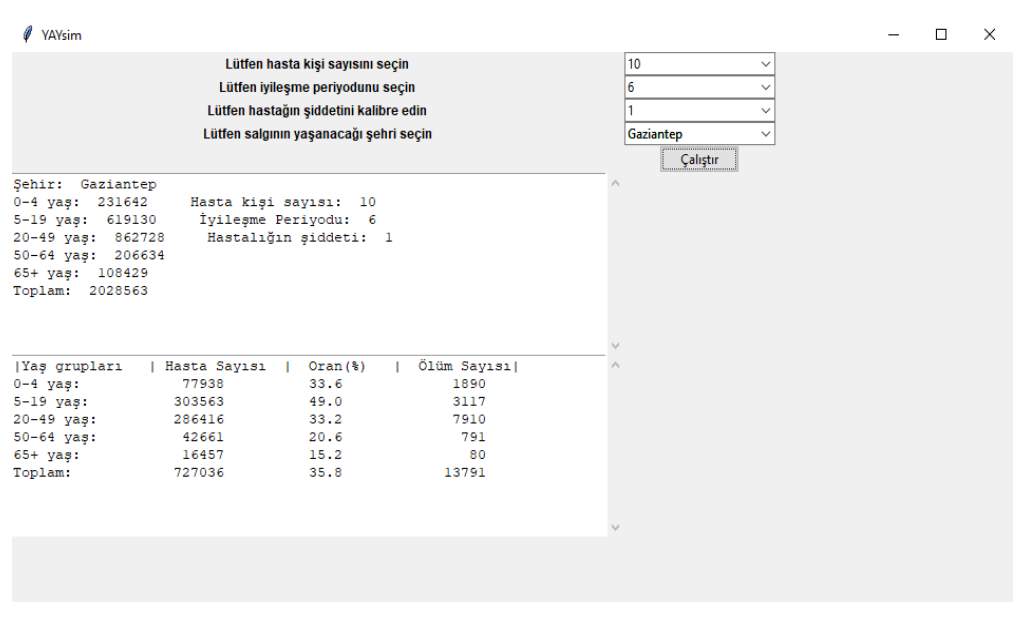

Şekil 4. YAYsim bilgi ve sonuç ekranı

Gaziantep nüfusunun \%35.8'i hastalıktan etkilenmiş ve \%0.7'si hayatını kaybetmiştir. Yaş gruplarına göre hastalık oranlarına baktığımızda en çok etkilenen grubun 5-19 yaş aralığında yer alan bireylerden oluştuğunu görmekteyiz. Bu aşamada, karar vericiler okulların bir süre tatil edilmesine ve bu yaş aralığındaki bireylerin bir süre evde kalmasına karar verebilirler. Ölüm sayılarına baktığımızda en çok ölen bireylerin 20-49 yaş aralı̆̆ında olduğu gözlenmektedir. Ölüm oranlarını azaltmak için bu yaş aralığındaki bireylere aşı ve antiviral ilaç dağıtımı için öncelik verilebilir. Başlangıçtaki hasta kişi sayısı ve iyileşme periyodu sonuçlar üzerinde önemli etkileri olduğundan, ilaç tedavileriyle iyileşme süreci hızlandırılabilir veya havaalanları veya 
otogarların daha sıkı denetlenmesiyle başlangıçtaki hasta kişi sayısı azaltılabilir. Örneğin iyileşme periyodu 6 günden 4 güne düşürülebilirse toplam hasta sayısı yüzbinlerden yüzlere, ölüm sayısı ise onlara düşmektedir.

Bununla beraber, hastalığın yayılması sonucunda oluşacak hasta kişi ve ölüm sayılarına göre karar vericiler, sağlık personeli, ilaç, aşı vb. gibi hastalıkla savaşmak için gerekli olacak malzeme ve işgücünü ayarlayabilirler.

\section{SONUÇLAR}

Bulaşıcı hastalıklar asırlardır toplumları olumsuz olarak etkilemekte, büyük insan ve para kayıplarına neden olmaktadır. Mevsimsel epidemik veya pandemiklerin etkisini azaltabilmek için karantina, aşılama, antiviral ilaçlar, okul ve işyeri tatilleri gibi önlemler alınabilmekte fakat bu önlemlerin işe yaraması için hastalık dinamiklerinin belirlenmesi gerekmektedir. Endemik veya pandemiğin sonucunda oluşabilecek toplam hasta kişi ve ölüm sayısı, bunların yaş gruplarına göre dağılımı, iyileşme periyodu, hastalık şiddeti, ve başlangıç hasta sayısı gibi parametlerin etkisini önceden tahmin edebilmek, uygulanacak müdahalelerin etkinliğini de büyük ölçüde artıracaktır. Bu çalışmada, YAYsim isimli karar destek sistemi geliştirilip, ilgilenen kullanıcıların hizmetine sunulmuştur. YAYsim, Türkiye genelinde veya herhangi bir ilinde, yukarıda belirtilen hastalık parametrelerine göre meydana gelecek olan bir salgında, nüfusun farklı yaş gruplarına göre nasıl etkileneceğini hasta kişi ve ölüm sayılarına göre tahmin edilmesinde kullanılan bir programdır. En önemli ve ayırıcı özelliği kullanımının basit olması ve Türkiye'deki güncel demografik yapıyı içermesidir. Örnek çalışmada Gaziantep ilinde meydana gelebilecek olası bir H1N1 salgınının sonuçları incelenmiştir. Bu sonuçlara göre Gaziantep nüfusunun \%35.8'i hastalıktan etkilenmiş ve \%0.7'si hayatını kaybetmiştir. Özellikle hastalığın genç popülasyon üzerinde daha etkili olduğu görülmüş, buna göre okulların tatil edilmesi ve aşllamanın bu yaş grubu bireyler üzerinde yoğunlaştırılması önerilmiştir. Müdahale stratejileri ve alınacak önlemler farklı disiplinlerin çalışmaları bağlı olarak değişebilir. Örnek olarak, bir sağlıkçı açısından hasta ve ölüm sayıları, aşıların ve ilaçların öncelikli olarak hangi yaş gruplarına göre dağıtılmasını kararını vermelerine yardımcı olurken, aynı sayılar taktik ve stratejik seviyede doktor ve yardımcı personel ihtiyaç planlaması, ilaç-aşı-tıbbi malzemeler ihtiyaç tahmin ve üretim planlaması, olası bir karantina durumda gıda ve su ihtiyaçlarının ve güvenliğin temini gibi afet yönetimi alanına girebilecek kararların verilmesine yardım edebilir.

Programın basitliği bazı ön kabulleri de beraberinde getirmektedir. Benzetim parametreleri deterministiktir. Günlük kontak oranları, ölüm oranları, iyileşme periyodu her kişi için sabit kabul edilmiştir. Gerçek hayatta bu veriler olasılıklıdır. İkinci olarak benzetim bölmeli model kullanılarak tasarlanmıştır. Bölmeli modeller yüksek sayıda insan barındıran popülasyonları hızlıca modellemek için uygun olsada, şebeke tabanlı modeller kadar gerçek durumları yansıtamazlar.

Gelecek çalışmalarda yukarıdaki eksiklikleri giderecek şekilde şebeke tabanlı, gereken parametrelerin olasılıklı olarak modellenebildiği daha gelişmiş bir karar destek sistemi üzerine çalışmalar yapılabilir. Bunun yanında aşılama, ilaç tedavisi, karantina vb. gibi çeşitli müdahale tekniklerinin de modellerde yer alması düşünülebilir. Bu şekilde müdahale tekniklerinin, salgının yayılışı ve nihai sonuçlarının üzerindeki etkileri de gözlemlenebilir.

\section{KAYNAKLAR}

[1] Editorial (2018). How to be ready for the next influenza pandemic. Lancet Infect. Dis., 18(7), 697.

[2] Hawkey, S. (2019). Overview of ebola virus disease. WHO, https://www.who.int/healthtopics/ebola/\#tab=tab_1, (01/01/2020).

[3] Özkaya, H. (2016). Fight against contagious diseases during the period of the republic. Türkiye Aile Hekim. Derg., 20(2), 77-84.

[4] Kermack, W. O. and McKendrick, A. G. (1927). A Contribution to the Mathematical Theory of Epidemics. Proc. R. Soc. A Math. Phys. Eng. Sci., 115(772), 700-721.

[5] Walters, C. E., Meslé, M. M. I. and Hall, I. M. (2018). Modelling the global spread of diseases: A review of 
current practice and capability. Epidemics, 25, 1-8.

[6] Prieto, D. M., Das, T. K., Savachkin, A. A., Uribe, A., Izurieta, R., and Malavade, S. (2012). A systematic review to identify areas of enhancements of pandemic simulation models for operational use at provincial and local levels," BMC Public Health, 12(1), 251.

[7] Chao, D.L., Halloran, M.E., Obenchain, V.J. and Longini Jr, I.M., (2010). FluTE, a publicly available stochastic influenza epidemic simulation model. PLoS computational biology, 6(1), 1-8.

[8] Hladish, T., Melamud, E., Barrera, L.A., Galvani, A. and Meyers, L.A., (2012). EpiFire: An open source $\mathrm{C}++$ library and application for contact network epidemiology. BMC bioinformatics, 13(1), 76.

[9] Liu, S., Poccia, S., Candan, K.S., Chowell, G. and Sapino, M.L., (2016). epiDMS: data management and analytics for decision-making from epidemic spread simulation ensembles. The Journal of infectious diseases, 214, 427-432.

[10] Edlund, S.B., Davis, M.A. and Kaufman, J.H., (2010). The spatiotemporal epidemiological modeler. In Proceedings of the 1st ACM International Health Informatics Symposium, November, 817-820.

[11] Grefenstette, J.J., Brown, S.T., Rosenfeld, R., DePasse, J., Stone, N.T., Cooley, P.C., Wheaton, W.D., Fyshe, A., Galloway, D.D., Sriram, A. and Guclu, H., (2013). FRED (A Framework for Reconstructing Epidemic Dynamics): an open-source software system for modeling infectious diseases and control strategies using census-based populations. BMC public health, 13 (1), 940.

[12] Kuylen, E., Stijven, S., Broeckhove, J. and Willem, L., (2017). Social Contact Patterns in an Individualbased Simulator for the Transmission of Infectious Diseases (Stride). In ICCS, January, 2438-2442.

[13] Ramírez-Ramírez, L.L., Gel, Y.R., Thompson, M., de Villa, E. and McPherson, M., (2013). A new surveillance and spatio-temporal visualization tool SIMID: SIMulation of Infectious Diseases using random networks and GIS. Computer methods and programs in biomedicine, 110(3), 455-470.

[14] Hethcote, H.W., (2000). The mathematics of infectious diseases. SIAM review, 42(4), 599-653.

[15] Zaric, G.S. and Brandeau, M.L., (2001). Resource allocation for epidemic control over short time horizons. Mathematical Biosciences, 171(1), 33-58.

[16] Medlock, J. and Galvani, A.P., (2009). Optimizing influenza vaccine distribution. Science, 325(5948), 1705-1708.

[17] Mossong, J., Hens, N., Jit, M., Beutels, P., Auranen, K., Mikolajczyk, R., Massari, M., Salmaso, S., Tomba, G.S., Wallinga, J. and Heijne, J., (2008). Social contacts and mixing patterns relevant to the spread of infectious diseases. PLoS medicine, 5(3).

[18] Glezen, W.P., (1996). Emerging infections: pandemic influenza. Epidemiologic reviews, 18(1), 64-76. 